\title{
Reaction of antibodies to rheumatoid arthritis nuclear antigen with a synthetic peptide corresponding to part of Epstein-Barr nuclear antigen 1
}

\author{
PATRICK J W VENABLES, 'TOMMASZ PAWLOWSKI, 'PAT A MUMFORD,
} CHRISTINABROWN, 'DOROTHYH CRAWFORD, ${ }^{2}$ ANDRAVINDER N MAINI ${ }^{1}$

From the 'Division of Clinical Immunology, Kennedy Institute of Rheumatology, London; and the ${ }^{2}$ Department of Virology, Royal Postgraduate Medical School, London

SUMMARY Antibodies to rheumatoid arthritis nuclear antigen (RANA) are detected byo immunodiffusion (ID) and immunofluorescence (IF), though reports of the identity of the을 antigen(s) have been conflicting. In this study it is shown conclusively that ID and IF anti-RANA $\rightarrow$ react with epitopes on Epstein-Barr nuclear antigen 1 (EBNA-1) and that the major epitope $\frac{D}{0}$ detected by immunofluorescence is represented by a synthetic peptide, P62, corresponding to part of EBNA-1. In an enzyme linked immunosorbent assay (ELISA) anti-P62 antibodies in 350 rheumatoid arthritis sera were threefold higher than those of 35 age and sex matched controls, with the highest levels occurring in young patients with active joint disease.

Key words: Epstein-Barr virus.

Antibodies to rheumatoid arthritis nuclear antigen (RANA) were originally detected as precipitin reaction with Epstein-Barr virus (EBV) transformed cell lines in sera from $61 \%$ of patients with rheumatoid arthritis (RA) and $6 \%$ of controls. ${ }^{1}$ The demonstration that the antigen was detectable only in cell lines which had been transformed by the $\mathrm{EBV}^{2}$ led to speculation that EBV was a candidate pathogen in RA. This concept was not supported by seroepidemiological studies, which showed that the prevalence of EBV infection, as defined by the presence of antibodies to EB viral capsid antigen (VCA), was the same in RA and the normal population both in adults, ${ }^{34}$ and in children. ${ }^{56}$

More recently, evidence has accumulated suggesting that in patients with RA the regulation of EBV infection is impaired. This has been shown by defective $T$ cell control of EBV infected $B$ cells in vitro, ${ }^{7-10}$ increased numbers of copies of EBV genome in RA B cells, ${ }^{10} 11$ and by raised titres of antibodies to EBV antigens in RA. The regulatory defects are not restricted to EBV, however, nor has

\footnotetext{
Accepted for publication 10 October 1987.

Correspondence to Dr Patrick J W Venables, Division of Clinical Immunology. Kennedy Institute of Rheumatology, 6 Bute Gardens. London W6 7DW.
}

there been general agreement on the serological evidence. Although some studies have found raised titres of anti-EBVCA in patients with RA, ${ }^{12}{ }^{13}$. others have found them to be normal. ${ }^{14} 15$ In contrast with these discrepant findings, there is general agreement that anti-RANA antibodies are 3 . more frequent in RA and present in titres 2-16-fold higher than in controls. ${ }^{141213}$ This is in turn implies that anti-RANA antibodies may represent ao specific immune response to one EBV encoded antigen in RA.

The apparent selectivity of the immune response to RANA in RA has led to interest in the nature of $\tilde{N}$ the antigen itself. When first described its distinction N from EBNA was explored in detail by Alspaugh N et al. ${ }^{2}$ Furthermore, anti-RANA has been detected ${ }_{\sigma}^{\omega}$ in sera negative for anti-EBNA both in $\mathrm{RA}^{2}{ }^{4}$ and in infectious mononucleosis. ${ }^{16}$ The distinction between RANA and EBNA was later complicated by the description of at least two antigens, EBNA-1 and EBNA-2, which were recognised by anti-EBNApositive sera. ${ }^{17}$ It was then suggested that anti- $\mathbb{\mathbb { D }}$ RANA antibodies reacted with the EBNA-1 poly- $\frac{?}{\mathbb{D}}$ peptide by immunoblotting. ${ }^{18}{ }^{19}$ An explanation for $\cong$ differences between RANA and EBNA was that their respective antibodies reacted with different 8 
epitopes on the same polypeptide. These data were challenged by Sculley and his colleagues, ${ }^{20} 21$ who confirmed that RA sera reacted with EBNA-1 but that the greatest difference between RA and normal sera was in a reaction with a higher molecular weight (94 kilodalton) polypeptide that they identified as EBNA-2, ${ }^{21}$ which correlated with antibodies to RANA by immunofluorescence. Based on this evidence they suggested that EBNA-2 was the target for anti-RANA antibodies.

A recent report described the use of several synthetic peptides corresponding to sequences in EBNA-1 in enzyme linked immunosorbent assays (ELISA) for measuring anti-EBNA antibodies. ${ }^{22}$ Several peptides reacted strongly with RA sera, but the highest levels of binding and the greatest difference between RA and normal sera were found with a peptide, P62, containing 20 amino acids, corresponding to part of the internal repeat sequence of EBNA-1. In that study, however, the patients and controls were not age matched, nor was there any attempt to define whether the antibodies reacting with $\mathrm{P} 62$ had anti-RANA or anti-EBNA specificities, or both.

The purpose of this study was to use P62 to characterise antibodies reacting with RANA and EBNA-1 by immunofluorescence, Western blot, immunodiffusion, and ELISA in patients with RA and healthy controls. Because each of the antibody systems is operationally defined we have chosen the following nomenclature for each antibody system: anti-EBNA detected by anticomplementary immunofluorescence is termed ACIF anti-EBNA, and anti-EBNA-1 refers to antibodies detected by Western blot. Anti-RANA by indirect immunofluorescence is termed IF anti-RANA, and by immunodiffusion ID anti-RANA. The term antiP62 refers to specific antibodies detected by ELISA. We have also examined antibodies to P62 in a group of patients with RA and compared the results with those for age and sex matched controls to see whether, like anti-RANA, high titres of these antibodies are found in RA.

\section{Patients and methods}

PATIENTS AND SERA

Serum from 35 patients with classical or definite $\mathrm{RA}^{2.3}$ comprising 30 women and five men (mean age 49.6 years), and 35 healthy controls (F:M 30:5, mean age 49.9 years) were used in a controlled study for measuring antibodies to P62 by ELISA. Also tested were 30 younger patients with systemic lupus erythematosus (F:M 28:2, mean age $38 \cdot 4$ ) as disease controls.

Three reference sera were used for the detection of anti-RANA antibodies by immunofluorescence and immunodiffusion, and anti-P62 antibodies by ELISA. Serum No 1 was that used in our previous study ${ }^{+}$and was used in the immunodiffusion experiments. Serum No 2, strongly positive for antiRANA and anti-P62, was used as the standard serum for anti-P62 ELISA and for the affinity purification of anti-RANA antibodies. Serum No $3,{ }^{2+}$ from a healthy donor, was used because this had been previously characterised as containing only antibodies to EBNA-1 by immunoblotting.

ENZYME LINKED IMMUNOSORBENT ASSAY (ELISA) FOR ANTI-P62

The antigen, P62, with the amino acid sequence GAGGGAGGAGAGGGAGGAGA conjugated to a single cysteine residue was used exactly as previously described ${ }^{22}$ with serum dilutions of 1:20 and 1:320 except that results were expressed in relation to a standard curve of serial dilutions of serum No 2 in order to standardise the assay and to improve measurement of antibody in serum. Because column fractions often gave results falling above or below the standard curve these results were expressed as optical density units. In each case such fractions were assayed on the same ELISA plate.

AFFINITY PURIFICATION OFANTI-P62 AND

ANTI-RANA ANTIBODIES

Affinity columns were prepared by coupling $1 \mathrm{mg}$ of $\mathrm{P} 62 / \mathrm{ml}$ of gel to cyanogen bromide activated Sepharose (Pharmacia, Hounslow, Middlesex, UK) followed by blocking with $2 \mathrm{M}$ glycine $\mathrm{pH} 8.0$ according to the manufacturer's instructions. Control columns, conjugated with glycine or alanine were prepared in the same way but the initial conjugation with P62 was omitted. Poly-L-lysine coupled to Sepharose was purchased commercially (Pharmacia). Because 1:20 was the optimal dilution for detecting IF anti-RANA, all column fractions were recovered at a dilution equivalent to $1: 20$ by taking $5 \mathrm{ml}$ fractions from an original applied volume of $250 \mu \mathrm{l}$ of serum. Each serum $(250 \mu \mathrm{l})$, followed by $100 \mu \mathrm{l}$ of phosphate buffered saline (PBS), was run into $1 \mathrm{ml}$ affinity columns and left for one hour at $20^{\circ} \mathrm{C}$ in the gel. The flow through was collected by running $5 \mathrm{ml}$ of PBS through the column. After a further wash with $200 \mathrm{ml}$ of PBS, bound antibody was eluted with $5 \mathrm{ml}$ eluting buffers: $(0.1 \mathrm{M}$ glycine, $0.5 \mathrm{M} \mathrm{NaCl} \mathrm{pH} \mathrm{2.5;1} \mathrm{M} \mathrm{guanidine} \mathrm{HCl}$ and/or $3 \mathrm{M}$ guanidine $\mathrm{HCl}$. Each column fraction was dialysed separately with 1 litre of PBS over 48 hours with three changes of buffer and then tested by immunofluorescence for IF anti-RANA using the modified method described by Alspaugh et al, ${ }^{25}$ by ACIF for 
anti-EBNA antibodies, ${ }^{2+}$ by ELISA for anti-P62, and by immunoblotting for anti-EBNA-1.

Because anti-RANA antibodies on immunodiffusion were found to react optimally with a serum dilution of $1: 4$ a similar method to that above, but with an $8 \mathrm{ml}$ affinity column containing $16 \mathrm{mg}$ of P62, was used to purify antibody from $2 \mathrm{ml}$ of serum No 2. The original serum, an $8 \mathrm{ml}$ flow through, and $8 \mathrm{ml} 3 \mathrm{M}$ guanidine eluate, each corresponding to a serum dilution of $1: 4$, were tested on immunodiffusion with WI-L2 extract and P3HR-1 as previously described. ${ }^{4}$ Also treated on immunodiffusion were P62 (unconjugated), P62 conjugated to human serum albumin (HSA) with a molar ratio of approximately 10:1, and P62 conjugated to keyhole limpet haemocyanin (KLH) (ratio 2:1). The conjugates $^{22}$ were tested at concentrations of 200 , 20 , and $2 \mu \mathrm{g} / \mathrm{ml}$ of $\mathrm{P} 62$.

IMMUNOBLOTTING OF EBNA-1

For immunoblotting $5 \mu \mathrm{l}$ extracts from WI-L2, P3HR-1, and Raji containing approximately $30 \mathrm{mg} / \mathrm{ml}$ of protein, and $5 \mu \mathrm{l}$ of the conjugates each containing $10 \mu \mathrm{g} / \mathrm{ml}$ of P62 were loaded into the wells of a 5-15\% gradient gel prepared as previously described. ${ }^{26}$ For immunoblotting of precipitins the immunodiffusion gel in Fig. 1 was used. After washing for five days in PBS the precipitins were cut

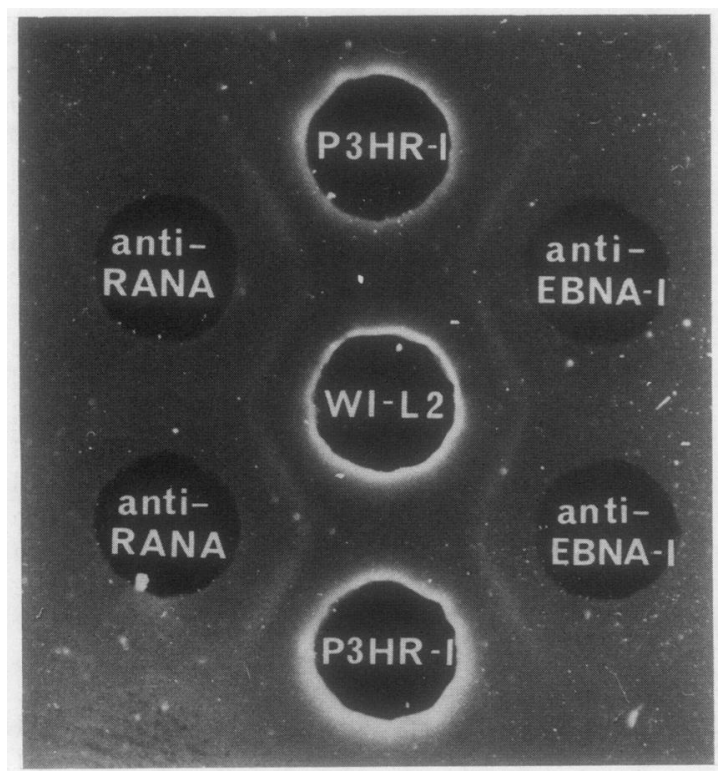

Fig. 1 Immunodiffusion experiment showing RANA in both WI-L2 extract and P3HR-1 reacting with an anti-RANA reference serum (No $1,1: 4)$ and a serum containing only antibodies to EBNA-1 (No 3, 1:2). out in $2 \mathrm{~mm} \times 5 \mathrm{~mm} \times 2 \mathrm{~mm}$ slices. The four oppositex? the well containing WI-L2 extract and the four opposite that containing P3HR-1 were each amal $\stackrel{5}{?}$ gamated as WI-L2 and P3HR-1 precipitins respect읃 ively. Slices from two areas of gel, each $2 \mathrm{~mm} \times \overline{\underline{\underline{n}}}$ $10 \mathrm{~mm} \times 2 \mathrm{~mm}$, immediately above and below the P3HR-1 wells in which no precipitins were seen $\stackrel{1}{2}$ were amalgamated as the control. The precipitins were prepared by boiling them twice with $50 \mu \mathrm{l}$ concentrated starting buffer and quickly applyingthem to a polyacrylamide gel before the agarose $\vec{\omega}$ reset. For the immunoblotting of multiple fractions on one antigen the cassette described by Williamsō et al was used. ${ }^{26}$ The transfer to nitrocellulose incubation with antibody, diluted 1:100, and $\triangle$ development with a peroxidase based ELISA method was also as reported by Williams et al. ${ }^{26}$

\section{Results}

REACTION OF ANTI-RANA ANTIBODIES ON IMMUNODIFFUSION WITH EBNA-1

When tested by immunodiffusion serum No 1 (anti RANA) and serum No 3 (anti-EBNA-1) reacted both with WI-L2 and P3HR-1 with a line of complete immunological identity between the two cell extracts (Fig. 1). In other experiments (not) shown) serum No 3 precipitin gave a line of complete identity with serum No 1 to a titre of $1 / 8$. $\overrightarrow{0}$ Because serum No 3 lacked antibodies to EBNA- $2^{3}$ and because P3HR-1 does not contain EBNA-2 we concluded that the RANA precipitin did not contain EBNA-2. The presence of EBNA-1 in the precipitin was confirmed by immunoblotting of the precipitins together with EBV transformed cell lines in which the EBNA-1 polypeptide has a known variablen molecular weight: 80 kilodaltons in WI-L2, 78 kilo 3 daltons in P3HR-1, and a lower molecular weighto polypeptide in Raji (72 kilodaltons) (Fig. 2). There was only a very weak reaction with EBNA-1 in geto cut from an area in which there was no visible precipitin. There was also a reaction with HSAO conjugated to P62, migrating as a diffuse bandin between 80 and 100 kilodaltons with some highen molecular weight bands. This confirmed that P62 was immunoreactive on blotting and that there were on average 10 P62 peptides on each HSA molecule, accounting for its increased molecular weight. क

REACTION OF ANTI-RANA ANTIBODIES WITH P62 AND EBNA-1

On indirect immunofluorescence P3HR-1 was founc to give the characteristic discrete speckled staining pattern when tested with anti-RANA reference serak (Fig. 3). Serum No 2 was purified by affinity 
chromatography, and bound antibody eluted with three different buffers (Table 1). Relatively low concentrations were found in the acid and $1 \mathrm{M}$ guanidine eluates, most of the antibody being recovered from the $3 \mathrm{M}$ guanidine eluate. This showed that in this serum most of the antibody was of high affinity and its antigen specificity was not

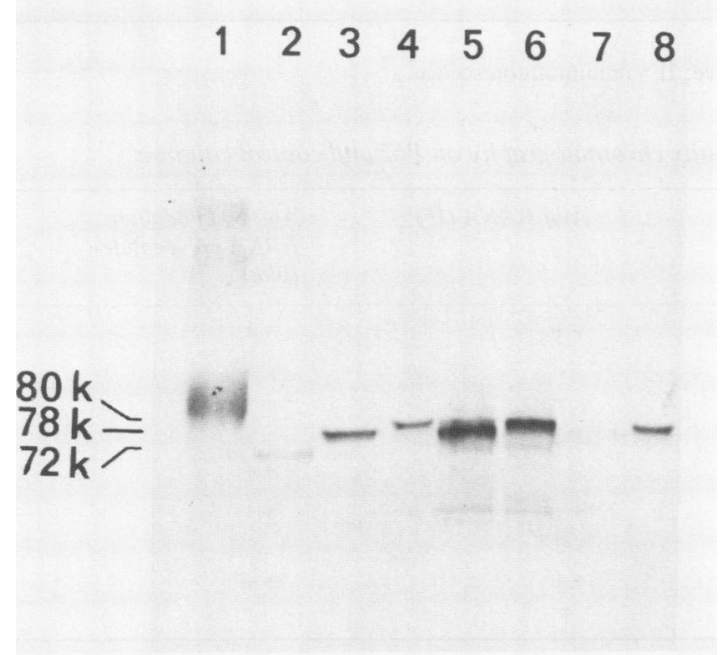

Fig. 2 Western blot with serum No $2(1: 100)$ as a probe. Reactivity with bands in the P62 human serum albumin conjugate (lane 1), EBNA-I in Raji cell extract (lane 2), P.3HR-I (lane 3). WI-L2 (lane's tand 8), and with precipitins cut from the immunodiffusion gel in Fig. I (lanes 5 and 6). Lane 5: P.3HR-I precipitin, lane 6: WI-L2 precipitin. lane 7: control area of gel. denatured by $3 \mathrm{M}$ guanidine. When tested for antiEBNA by ACIF the original serum and the flow through were positive for anti-EBNA. The acid eluate was weakly positive, but the guanidine eluate was negative. In contrast, anti-RANA, also strongly positive in the original serum, was recovered from the $3 \mathrm{M}$ guanidine eluate and was not detectable in the flow through. All fractions except the $1 \mathrm{M}$ guanidine eluate reacted with the 80 kilodalton EBNA polypeptide by Western blot; the strongest reaction (judged by the intensity of staining of the band on the nitrocellulose) was with the $3 \mathrm{M}$ guanidine eluate.

Because $3 \mathrm{M}$ guanidine recovered most of the antibody bound to the $\mathrm{P} 62$ column this buffer was used to elute antibody from specificity control columns. When serum No 2 was used on four different columns, anti-P62, as expected, bound to the P62 column. Surprisingly, some anti-P62 antibody, but not IF anti-RANA, also bound to the glycine conjugated column, suggesting that a proportion of anti-P62 antibodies bound to glycine residues alone. There was no binding to columns coupled to alanine or to poly-l-lysine (Table 2).

These experiments led us to adopt the following protocol for examining further sera. Each serum was passed first through the glycine conjugated column to absorb antiglycine antibodies, then through the P62 column, and the flow through collected. The two columns were disconnected and each eluted separately with $3 \mathrm{M}$ guanidine (Table 3 ). In each case anti-EBNA was detected in the flow through but not in the eluate, whereas anti-RANA activity was abolished in the flow through and recovered in

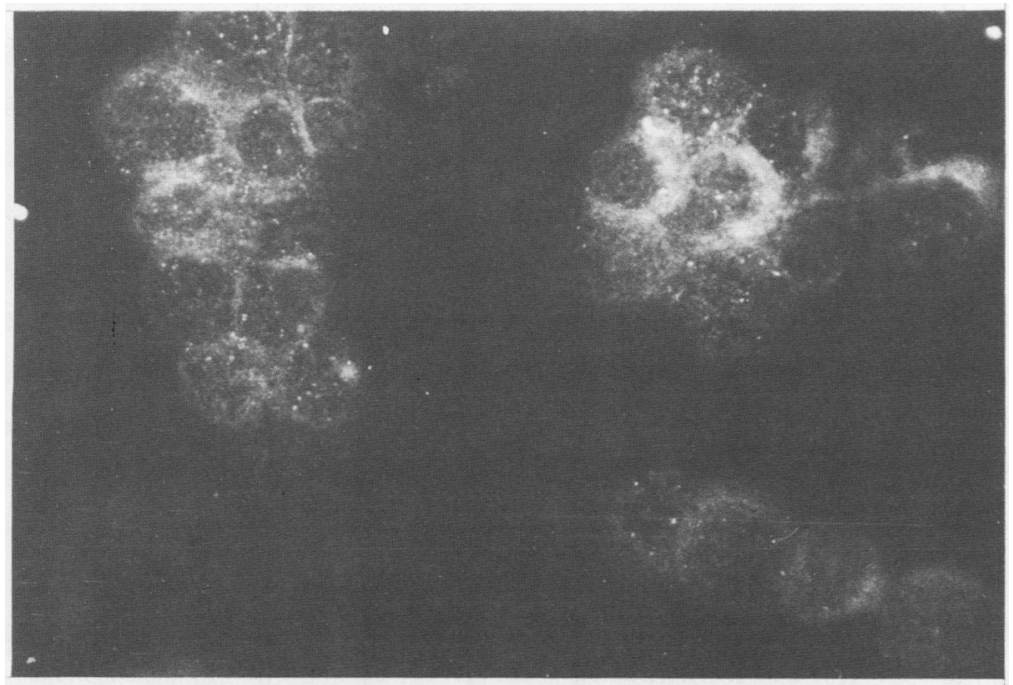

Fig. 3 Immunofluorescence showing characteristic $R A N A$ staining pattern on P.3HR-I (serum No 2 at 1:20). 
274 Venables, Pawlowski, Mumford, Brown, Crawford, Maini

Table 1 Reactivity of fractions purified from serum No 2 by affinity chromatography on a P62 column

\begin{tabular}{|c|c|c|c|c|}
\hline & $\begin{array}{l}\text { Anti-P62 ELISA } \\
\left(O D{\text { units })^{+}}^{-}\right.\end{array}$ & $\begin{array}{l}\text { Anti-EBNA } \\
(A C I F)^{\dagger}\end{array}$ & $\begin{array}{l}\text { Anti-RANA } \\
(I F)^{\dagger}\end{array}$ & $\begin{array}{l}\text { Anti-EBNA-I } \\
\text { (iimmunoblot) }\end{array}$ \\
\hline Serum $(1: 20)$ & 1500 & +++ & ++ & ++ \\
\hline Flow through* & 38 & ++ & - & + \\
\hline Acid eluate & 235 & + & - & + \\
\hline $1 \mathrm{M}$ guanidine eluate & 20 & - & - & - \\
\hline $3 \mathrm{M}$ guanidine eluate & 1500 & - & ++ & +++ \\
\hline
\end{tabular}

*All column fractions equivalent to a serum dilution of 1:20.

$+\mathrm{OD}=$ optical density; $\mathrm{ACIF}=$ anticomplementary, immunofluorescence; $\mathrm{IF}=$ immunofluorescence.

Table 2 Reactivity of fractions of serum No 2 separated by affinity chromatography on P62 and control columns

\begin{tabular}{|c|c|c|c|c|}
\hline & & $E L I S A(O D)$ & Anti-RANA $(I F)$ & $\begin{array}{l}\text { Anti-80 kilodalton } \\
\text { EBNA polypeptide } \\
\text { (blot) }\end{array}$ \\
\hline Serum $(1: 20)$ & & 1400 & ++ & ++ \\
\hline P62: & $\begin{array}{l}\text { Flow through } \\
\text { Eluate }\end{array}$ & $\begin{array}{r}215 \\
1290\end{array}$ & $\begin{array}{l}- \\
+\end{array}$ & $\begin{array}{r}+ \\
++\end{array}$ \\
\hline Glycine: & $\begin{array}{l}\text { Flow through } \\
\text { Eluate }\end{array}$ & $\begin{array}{l}1227 \\
1223\end{array}$ & $\begin{array}{r}++ \\
-\end{array}$ & $\begin{array}{r}+ \\
++\end{array}$ \\
\hline Alanine: & $\begin{array}{l}\text { Flow through } \\
\text { Eluate }\end{array}$ & $\begin{array}{r}1352 \\
71\end{array}$ & $\begin{array}{r}++ \\
-\end{array}$ & $\begin{array}{r}++ \\
-\end{array}$ \\
\hline Lysine: & $\begin{array}{l}\text { Flow through } \\
\text { Eluate }\end{array}$ & $\begin{array}{r}1338 \\
63\end{array}$ & $\begin{array}{r}++ \\
-\end{array}$ & ++ \\
\hline
\end{tabular}

Table 3 Reactivity of fractions of sera passed sequentially through a column coupled to glycine (polyglycine) followed by a P62 column

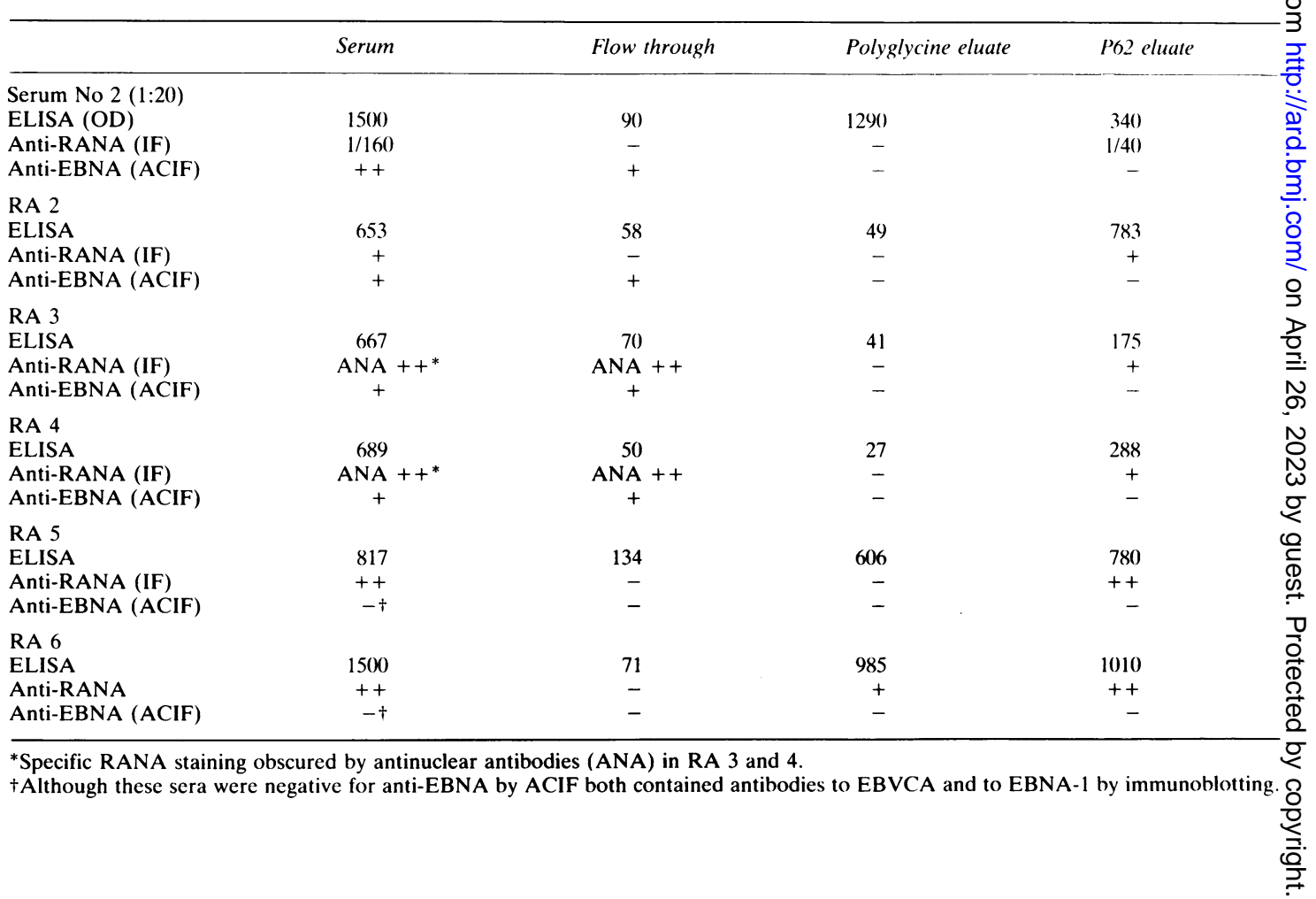


the eluate (Fig. 4). Two sera, RA 3 and 4, were deliberately selected for the presence of high titre antinuclear antibodies (ANA), one homogeneous and one speckled, which obscured any specific RANA staining. The ANA were recovered in the flow through. whereas the eluates, which had been completely cleared of ANA staining, showed the characteristic RANA staining pattern. Two further sera. RA 5 and 6 , were tested because they were IF anti-RANA positive but ACIF anti-EBNA negative.
It is of interest that in one of these the eluate from the glycine column contained anti-RANA activity.

Affinity chromatography was also used to characterise anti-RANA antibodies detected by immunodiffusion. Because this assay requires higher concentrations of serum to produce a precipitin, a serum dilution of 1:4 and column fractions equivalent to a serum dilution of $1: 4$ were used. ID anti-RANA was detected in the serum and the flow through but not in the eluates from either the glycine or the $\mathrm{P} 62$
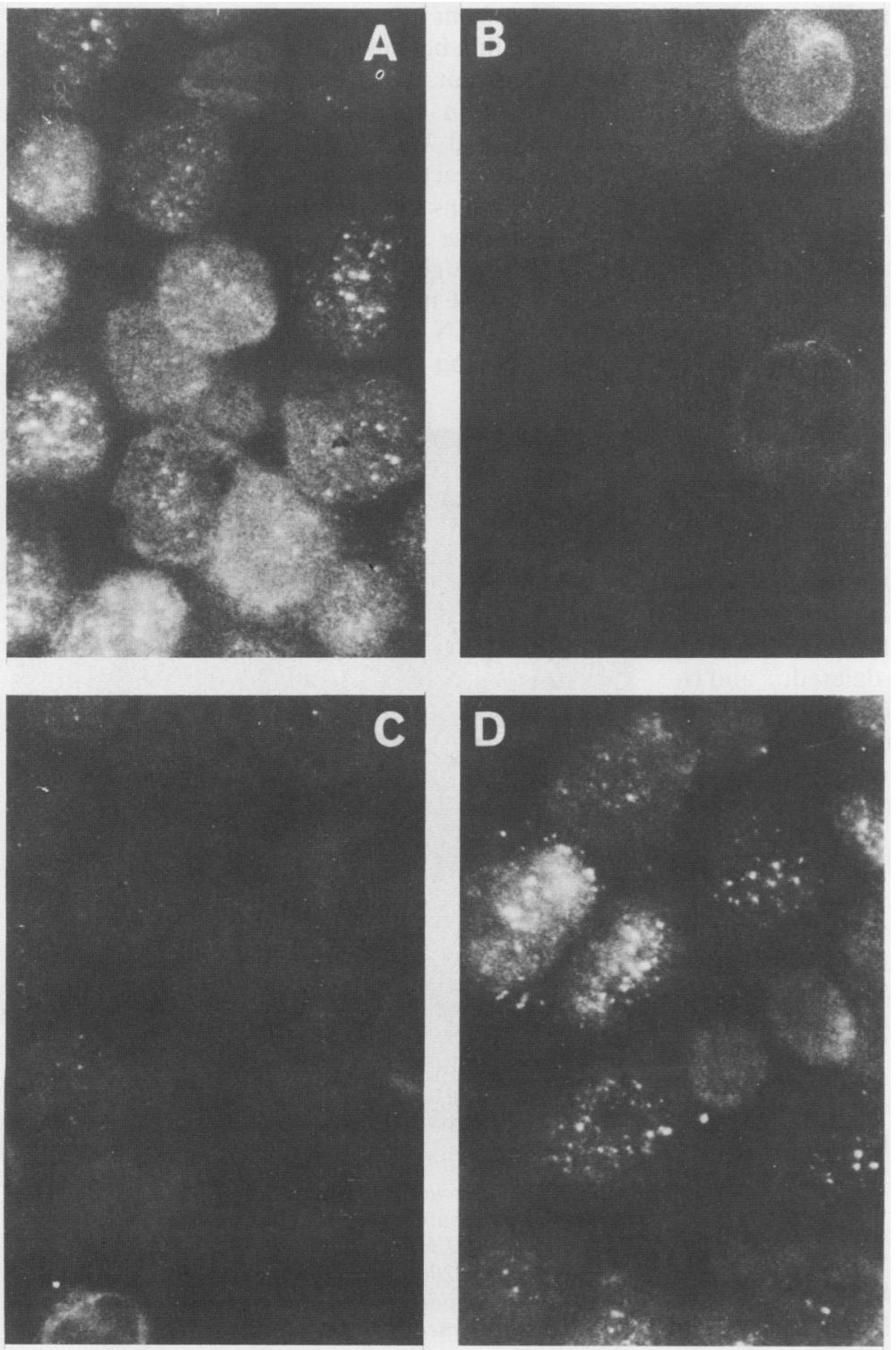

Fig. 4 Anti-RANA

immunofluorescence of fractions from affinity chromatography with P62. (A) Serum No 2 1:20 on WI-L2 cells; $(B)$ control with conjugate alone; (C) flow through showing depletion of anti-RANA activity; and $(D)$ eluate from the P62 column showing anti-RANA staining. 
column. There was depletion of anti-RANA activity in the flow through from the columns, however, in that the titre fell from $1 / 128$ to $1 / 16$. In addition, we attempted to purify anti-RANA antibodies by elution from the P62 column without preabsorbing with glycine, and again no precipitins were seen in the eluate. We also tested P62, P62 conjugated to $\mathrm{KLH}$, and P62 conjugated to HSA as antigens on immunodiffusion. At concentrations of 2, 20), and $200 \mu \mathrm{g} / \mathrm{ml}$ neither P62 alone nor the HSA or KLH conjugates formed precipitins with three anti-RANA sera (Nos 1, 2, and 3) or with the eluate recovered from the P62 column (Fig. 5).

By ELISA, serum No 2 bound to $\mathrm{P} 62$ at dilutions greater than 1:30 (0)(0) and was used as the standard serum. With screening dilutions of 1:20) the RA sera were found to contain anti-P62 antibodies in titres twofold higher than those of the age and sex matched controls (not shown), and at a screening dilution of $1: 320$. the titres were 3.5 times higher (Fig. 6). Of the 35 patients with RA tested, very high levels (greater than five standard deviations above normal) were found in four. All four were young (aged less than 35). DR4 positive, and had active joint disease. Only one was receiving second line antirheumatic treatment

\section{Discussion}

This study has conclusively shown that both IF and ID anti-RANA antibodies react with the EBNA-1. The recent suggestion that anti-RANA antibodies react with EBNA-2 was based on correlative data, and is contradicted by our findings that both ID and IF RANA are detectable in P3HR-1, a cell line in which the EBNA-2 gene has been deleted, ${ }^{27}$ and by the finding that a serum lacking EBNA-2 antibodies reacted with RANA both by immunofluorescence and immunodiffusion. The reaction with EBNA-1 was confirmed by immunoblotting RANA precipitins. A similar experiment was also reported by Billings et al with the same result, though they did not illustrate their findings in a figure. ${ }^{1 \times}$

Our data suggest that $\mathrm{P} 62$ contains the major epitope recognised by IF anti-RANA antibodies. Antibodies were depleted by a single passage through the P62 column and then recovered from the eluate in six RA sera. This suggests that the short amino acid sequence contains most if not all of the epitopes recognised by IF anti-RANA. This may be because P62 contains all possible epitopes on the IR3 region of the EBNA-1 peptide: it has two glycine triplets, two glycine doublets, and three single glycine residues each separated from each other by single alanine residues.

In contrast with IF anti-RANA, ACIF antiEBNA did not appear to react with P62, though it is possible that treatment with $3 \mathrm{M}$ guanidine. even after dialysis back into saline, affected the complement fixing abilities of the antibody. This possibility is supported by the recovery of some ACIF antiEBNA reactivity in the acid eluate. Nevertheless. the recovery of ACIF anti-EBNA in the flow through suggests that antibodies detected by this technique have a more diffuse reactivity. including epitopes on EBNA-2. ${ }^{17}$ These findings also explain discrepancies between anti-RANA and anti-EBNA which have been observed in sera from patients with RA (including two sera in this study). from those With Burkitt's lymphoma, ${ }^{-}$and in those from patients recovering from infectious mononucleosis. ${ }^{\text {(1) }}$

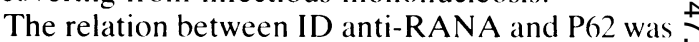
not so clear cut. We were not able to show a precipitin reaction between affinity purified anti-P62 antibodies and WI-L2 extract and there were no precipitins detected between $\mathrm{P} 62$ (alone or conjugated to proteins such as KLH or albumin) and antiRANA positive reference serit. The fall in titre in the flow through, however, supports our earlier suggestion that more than one antigen may play a part in the RANA precipitin reaction, and that one of these may be represented by P62. ${ }^{+11}$ The exact

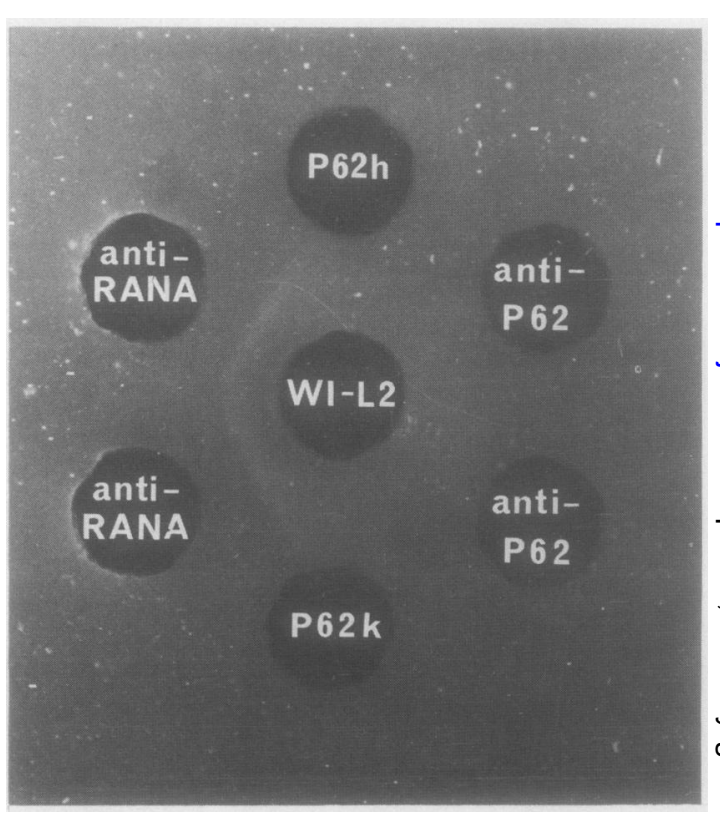

Fig. 5 Immunodiffusion showing no reaction be'w'e'n an anti-RANA reference serum $\left.\left(N_{0}\right) I\right)$ and $P 62$ conjugated lo human serum albumin (HSA) (P62h) or to kevhole limper haemocyanin $(K L H)(P 62 k)$, each containing $P(62$ al a concentration of $200 \mathrm{\mu g} / \mathrm{ml}$. There is no reaction betwee'n anti-P62 affinity purified from serum No 2 with WI-L2? extract or with either of the conjugates. 
specificity of ID anti-RANA antibodies remains unknown, though we can be certain that major epitopes lie on EBNA-1. Our findings also challenge the assumption that ID anti-RANA and IF antiRANA are the same.

We have previously suggested that the higher titres of ID anti-RANA antibodies in RA, and the finding of anti-RANA antibodies in sera from patients free of EBV infection, could be due to cross reactive autoantibodies. In this study cross reactions were found between antibodies binding to a glycine conjugated column (antiglycine antibodies), antiP62, and anti-EBNA-1 by immunoblotting. Specificity was proved by showing no binding to columns conjugated with alanine or lysine. Such a cross reaction is perhaps not surprising when it is considered that 13 of the 20 amino acids which comprise P62 are glycine residues. It is possible that such a cross reaction could account for the range of host proteins also reactive with IgM anti-EBNA-1 from infectious mononucleosis sera. ${ }^{2 \delta}$ Although we demonstrated a cross reaction between antiglycine

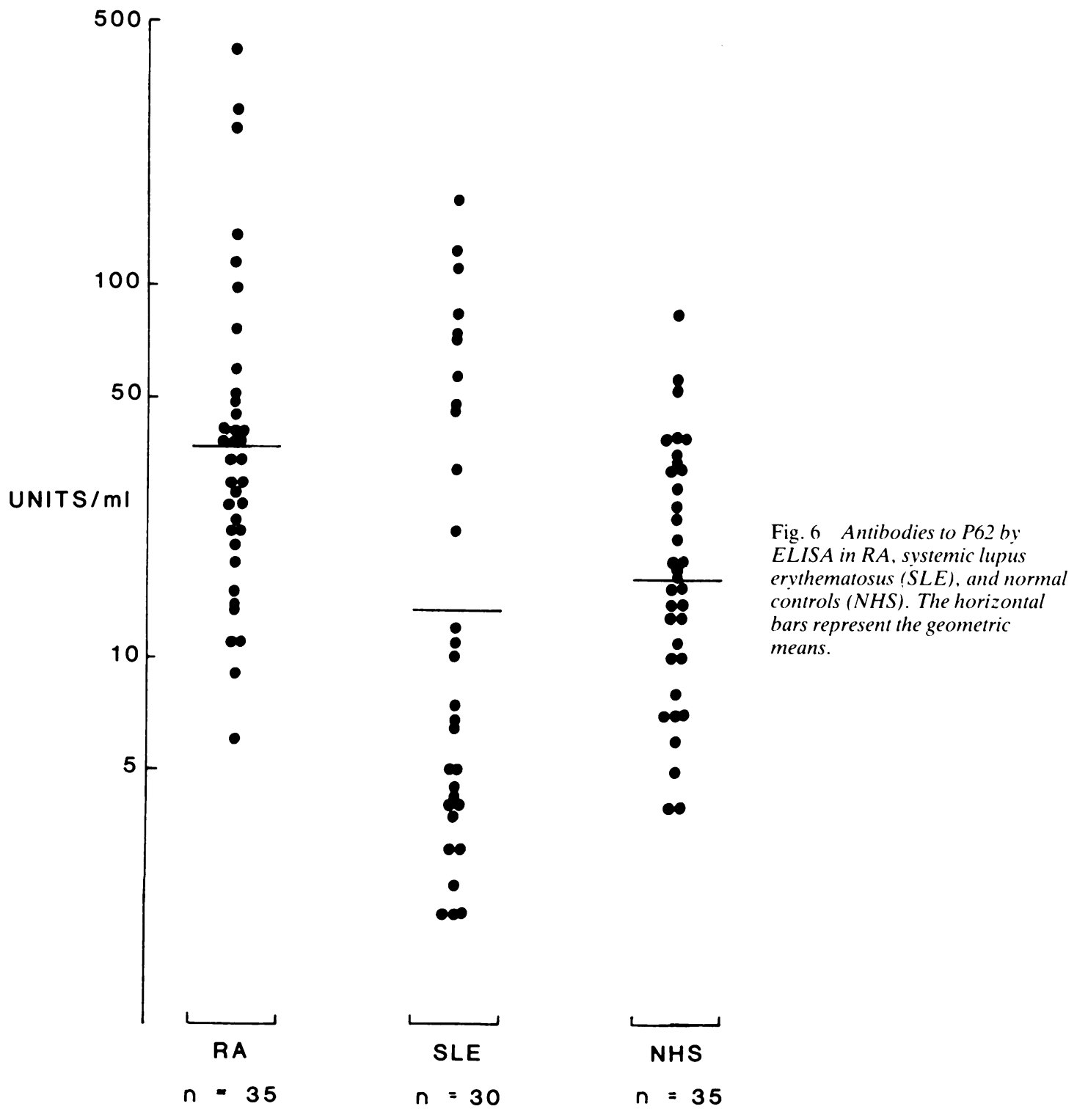


and IF anti-RANA in only one out of six RA sera tested, it is possible that antiglycine antibodies could increase the titres of IF anti-RANA and anti-P62 in RA sera. This was supported by the finding that sera from the three patients with the highest levels of anti-P62 antibodies (serum No 2, RA 5, and RA 6) also contained the largest proportion of their antibody binding to the glycine conjugated column.

Repeat sequences containing glycine are commonly found in structural proteins, a particularly striking example being cytokeratin, which contains several glycine triplets alternating with serine. ${ }^{29}$ It is possible that $\mathrm{IgG}$ autoantibodies to keratin, which have been reported in $\mathrm{RA},{ }^{30}$ may be cross reactive with P62. A more intriguing possibility is suggested by a recent study which demonstrated a host protein in the cytoplasm of cells in the lining layer of rheumatoid synovial membranes which reacted with a monoclonal antibody to EBNA-1. ${ }^{31}$ If the same antigen were recognised by anti-P62 antibodies from rheumatoid sera it could, for the first time, demonstrate mechanisms whereby anti-RANA could be related to an important antigen within the synovial membrane.

As anti-P62 by ELISA and IF anti-RANA are detecting the same antibodies it is perhaps disappointing that in our study RA sera contained antiP62 antibodies in titres only two to three times greater than those of controls. This seems to be a trivial increase in titre compared with the increase reported for IF anti-RANA by $\mathrm{Ng}$ et al, ${ }^{32}$ who showed such a difference between RA and normal sera $(97 \%$ positive $v 16 \%)$ that their claim that antiRANA was a 'marker' antibody for RA seemed to be justified. More recent studies using immunofluorescence have not found such differences, however: in most cases titre differences of two to four dilutions have been reported,,$^{22.33} .3+$ and these are much more in accord with our findings and those of Rhodes et al using a P62 ELISA.22 We suggest that ELISA merits further investigation as it is objective, quickly performed, and not susceptible to the errors of interpretation which can occur when attempting to assess end points of dilutions on immunofluorescence. Our survey is small, but even with the limited numbers that we have examined so far we have found sera with very high levels of anti-P62 antibody. The possibility that these represent a subset of RA which may be of clinical or immunogenetic significance is presently under investigation.

We would like to thank Dr Garry Rhodes. Scripps Clinic. California, for the generous gifts of the P62 peptide. the P62 conjugates, and for helpful discussion. We would also like to thank Dr David Williams and Martin Stocks for preparing the cell extracts and for technical help.

\section{References}

1 Alspaugh M A. Tan E M. Serum antibody in rheumatoid arth- $\overrightarrow{\vec{F}}$ ritis reactive with a cell associated antigen. Arthritis Rheum $\mathscr{S}$ 1976; 19: 711-9.

2 Alspaugh M A. Jensen F C. Rabin H. Tan E M. Lymphocytes transformed by $E B$ virus: induction of nuclear antigen reactive with serum antibody in rheumatoid arthritis. J Exp Med 1978: 147: 1018-27.

3 Elson C J. Crawford D H. Bucknall R C. et al. Infection with EB virus and rheumatoid arthritis. Lancet 1979: i: 105.

4 Venables P J W. Roffe L M. Erhardt C C. Maini R N. Edwards $\vec{O}$ J M B. Porter A D. Titers of antibodies to RANA in rheumatoid arthritis and normal sera: relationship to EpsteinBarr virus infection. Arthritis Rheum 1981; 24: 1459-64.

5 Phillips P E. Lim W N. Parkman P D. Harshut Y. Virus antibody and IgG levels in juvenile rheumatoid arthritis |Abstract|. Arthritis Rheum 1973: 16: 126.

6 Gear A J, Venables P J W, Edwards J M B. Maini R N. Ansell is B M. Rheumatoid arthritis, juvenile arthritis, iridocyclitis and the Epstein-Barr virus. Ann Rheum Dis 1986: 45: 6-8.

7 Slaughter L. Carson D A. Jensen F C. Holbrook T L. Vaughan J H. In-vitro effects of Epstein-Barr virus on peripheral blood mononuclear cells from patients with rheumatoid arthritis and normal subjects. $J$ Exp Med 1978; 148: 1429-34.

8 Bardwick P A. Bluestein H G. Zvaifler N H. Depper J M. Secgmiller J E. Altered regulation of Epstein-Barr virus induced lymphoblast proliferation in RA is due to a T-cell defect. J Immunol 1980): 127: 1899-9012.

9) Tosato G. Steinberg A D. Blaese R M. Defective Epstein-Barr virus specific suppressor T-cell function in rhcumatoid arthritis $N$ Engl J Med 1981: 305: 1238-43.

10 Tosato G. Blacse R M. Epstein-Barr virus infection and immunoregulation in man. In: Dixon $\mathrm{F} J$. ed. Advances in immunology. Vol 37. New York: Academic Press. 1985: 9)-149.

11 Tosato G. Steinberg A D. Yarchoan R, et al. Abnormally elevated frequency of Epstein-Barr virus-infected cells in the blood of patients with rheumatoid arthritis. J Clin Invest 1984: 73: 1789-95.

12 Alspaugh MA. Henle G. Lennette E T. Henle W. Elevated levels of antihodies of Epstein-Barr virus antigens in patients with rheumatoid arthritis. J Clin lnvest 1981: 67: 1134-40.

13 Ferrel F B. Aitcheson C T. Pearson G R. Tan E M. Scroepidemiological study of relationships between Epstein-Barr virus and rheumatoid arthritis. J Clin Invest 1981: 67: 681-7.

If (atalano M A. Carson D A. Slovin S F. Richaman D) D). Vaughan J H. Antibodies to Epstein-Barr virus determined antigens in normal subjects and patients with seropositive rhcumatoid arthritis. Proc Nat Acad Sci USA 1979); 76: 681-7.

15 Venables P J W. Ross M G R. Charles P J. Melsom R D. Griffiths P D. Maini R N. A seroepidemiological study of cytomegalovirus and Epstein-Barr virus in rheumatoid arthritis $N^{\circ}$ and sicca syndrome. Ann Rheum Dis 1985; 44: 742-6.

16 Catalano M A. Carson D A. Niederman J C. Feorino P. O Vaughan J H. Antibody to rheumatoid arthritis nuclear antigen: its relationship to in-vivo Epstcin-Barr virus infection. $J$ (Clin $O$ Invest 1980: 65: 1238-42.

17 Hennessy K. Keiff E. One of two Epstein-Barr virus nuclear antigens contains a glycine alanine copolymer domain. Proc $\mathbb{D}$ Nat Acad Sci USA 1983; 80: 5665-9.

18 Billings $\mathrm{P}$ B. Hoch S O. White P J. Carson D A. Vaughan J H. T Antibodies to Epstein-Barr nuclear antigen and to the rheumatoid arthritis nuclear antigen identify the same polypeptick. Proc Natl Acad Sci USA 1983; 80: 7104-8.

19 Venables P J W. Smith P R. Maini R N. Rheumatoid arthritis $\underset{Q}{\mathbb{Q}}$ nuclear antigen and Epstein-Barr virus. Arthritis Rheum 1984: 27: $476-7$.

20) Sculley T B. Walker P J. Moss D J. Pope J H. Identification of $\varrho$ 
multiple Epstein-Barr virus induced nuclear antigens with sera from patients with rheumatoid arthritis. J Virol 1984: 52: 88-93.

21 Sculley T B. Pope J H. Hazelton R A. Comparison between the presence of antibodies to Epstein-Barr virus nuclear antigen 2 and the rheumatoid arthritis nuclear antigen in rhcumatoid arthritis patients. Arthritis Rheum 1986: 29: 964-70.

22 Rhodes G, Carson D A, Valbract J, Houghten R, Vaughan J $\mathrm{H}$. Human immune repsonses to synthetic peptides from the Epstein-Barr nuclear antigen. J Immunol 1985; 134: 211-6.

23 Ropes M W. Bennett G A. Cobb S. Jacox R. Jessar R A. Revision of diagnostic criteria for rhcumatoid arthritis. Bull Rheum Dis 1958: 9: 175-6.

24 Crawford D H. Ando I. Epstcin-Barr virus infection is associated with B-cell maturation. Immunology 1986; 59: 405-9.

25 Alspaugh M A. Shoji H. Nonoyama M. A search for rhcumatoid arthritis-associated nuclear antigen and Epstein-Barr virus specific antigens or genomes in tissues and cells from patients with rheumatoid arthritis. Arthritis Rheum 1983; 26: 712-20.

26 Williams D G. Stocks M R. Charles P J. Maini R N. Antibodics to La, Jo-1, nRNP and Sm detected by multitrack immunoblotting using a novel filter holder: a comparative study with counterimmunoclectrophoresis using sera from patients with systemic lupus erythematosus and Sjögren's syndrome. J Immunol Methods 1986: 91: 65-73.

27 Erberg I, Kallin B, Dillner J, et al. Lymphoblastoid cell lines and Burkitt-lymphoma-derived cell lines differ in the expression of a second Epstein-Barr virus encoded antigen. Int J Cancer 1986: 38: 729-37.

28 Rhodes G. Rumpold R. Kurki P. Patrick K M. Carson D A. Vaughan $\mathbf{J} \mathbf{H}$. Autoantibodies in infectious mononucleosis have specificity for the glycine alanine repeating region of the Epstcin-Barr nuclear antigen. J Exp Med 1987: 165: 1026-40.

29 Fuchs E. Hanukoglu I. Unravelling the structure of the intermediate filaments. Cell 1983; 34: 332-4.

30) Kataaha P K. Mortazavi-Milani S M. Russell G. Holborow E J. Anti-intermediate filament antibodies, antikeratin antibody. and antiperinuclear factor in rheumatoid arthritis and infectious mononucleosis. Ann Rheum Dis 1985: 44: 446-9.

31 Fox R. Sportsman R. Rhodes G. Luka J. Pearson G. Vaughan $J$ H. Rheumatoid arthritis synovial membrane contains a 62.(0)()-molecular-weight protein that shares an antigenic epitope with the Epstein-Barr virus-encoded associated nuclear antigen. J Clin Invest 1986: 77: 1539-47.

$32 \mathrm{Ng} \mathrm{K} \mathrm{C.} \mathrm{Brown} \mathrm{K} \mathrm{A.} \mathrm{Perry} \mathrm{J} \mathrm{D.} \mathrm{Holborow} \mathrm{E} \mathrm{J.} \mathrm{Anti-RANA}$ antibody: a marker for seronegative and seropositive rheumatoid arthritis. Lancet 1980 ; i: 447-9.

33 Hay F C. Young A. Jones M G. Nincham L J. Malc D K. Roitt I M. Anti-globulins and circulating immune complexes in carly rhcumatoid arthritis. Clin Exp Immunol 1983; 54: 723-30.

34 Hazclton R A. Cross S M. Robert G. Strachan N. A family study of the prevalence of antibodies to the rheumatoid arthritis associated nuclear antigen (RANA). BrJ Rheumatol 1986; 25: 349-52. 